\title{
Economic appraisal of fish cultre: A case study from Gomati District in Tripura
}

\author{
RUBEN MOG, RAM SINGH AND S. M. FEROZE \\ College of Post-graduate Studies, Central Agricultural University, Imphal, Umiam - 793 103, Meghalaya, India \\ e-mail: ramsingh.cau@gmail.com
}

\begin{abstract}
Fish cultivation has been recognised as an emerging enterprise in India particularly in North-eastern states like Tripura. It is considered to be an important economic activity for generating income and gainful employment of rural people in Tripura. The present study examined the economic viability of fish culture in Gomati District of Tripura and the results revealed that the enterprise is quite profitable which requires a huge investment. The study recommends extending more research and development in this sector to enhance the area and production for ensuring sustainable livelihood and income to the farmers of the state.
\end{abstract}

Keywords: Economic appraisal, Fish culture, Tripura

\section{Introduction}

Fisheries is an important sector of food production in India, providing nutritional and livelihood security to a vast majority of the population and contributes significantly to the foreign exchange earnings. The inland fish production in India was estimated at 5.74 million $t$ with growth rate of $6.36 \%$, where as the marine fish production was 3.270 million $\mathrm{t}$ with growth rate of $1.63 \%$ during 2012-13. Since, the beginning of $21^{\text {st }}$ century, inland fish production in India has exceeded the marine fish production (DADF, 2013). Fishery contributes $1.07 \%$ to GDP and $5.3 \%$ to agricultural GDP (NFDB, 2014) in India. Among the fish growing countries in the world, India is the third largest fish producer and second largest producer of inland fish, next to China. During last few decades, the state of Tripura showed significant growth in fish production among all the North-eastern states to meet up the demand of fish in the state (DADF, 2013). Tripura, extends between $91^{\circ} 09^{\prime} \mathrm{E}$ to $92^{\circ} 20^{\prime} \mathrm{E}$ and $22^{\circ} 56^{\prime} \mathrm{N}$ and $24^{\circ} 32^{\prime} \mathrm{N}$, with an area of $10,492 \mathrm{sq} . \mathrm{km}$. The state is bordered on the north, west and south by Bangladesh and in the east bounded by Assam and Mizoram.

Tripura State is the second largest producer of fish among the North-eastern states after Assam. The production of different species of fish is a boon in terms of both employment and income generation to the fish farmers in Tripura. The total availability of fish (import and production) is estimated as 82.32 thousand $t$, and the total fish production in the state during 2012-13 from culture and capture was 58.66 thousand t (GoT, 2013). However, the state is not self-sufficient in fish production and it has to depend on other states like West Bengal and Andhra
Pradesh in order to meet the demand of fish. Consequently, 15.22 thousand $\mathrm{t}$ of fish was transported from other states during 2012-13 (GoT, 2013). Likewise, the state also depends on the neighboring country, Bangladesh in order to fill the gap of demand and supply of fish in the state which led to import of 8.45 thousand $t$ of fish during 2012-13 (GoT, 2013).

Fish cultivation in the state has direct or indirect impact on income and livelihood of farmers of Tripura State. Any adoption or rejection of the enterprise depends on its costs and returns. Therefore, considering the economic importance of fish culture in the state, economic appraisal of fish culture in the Gomati District of Tripura was attempted in the present study.

\section{Materials and methods}

Data

Both primary as well as secondary data were collected for the study. Primary data were collected from the sample households using pre-tested well structured schedule through interview method for the year 2014-15. Secondary data were collected from various published and unpublished sources viz., various research reports and bulletins of Central Agriculture University, Imphal, office of the North Eastern Council (NEC), ICAR Research Complex for NEH Region, Department of Agriculture, Directorate of Economics and Statistics and Directorate of Settlement and Land Revenue, Government of Tripura.

\section{Sampling plan}

The study was conducted in Gomati District of Tripura, being the largest producer of fish in the state. 
Out of the nine blocks in Gomati District, two blocks viz., Matarbari and Kakraban were selected on the basis of highest fish production. Out of the 57 villages of the two selected rural development blocks, 22 villages are in Kakraban block and 35 villages are in Matarbari block. Out of these, a total of 10 villages, with 5 villages from each blocks were selected randomly. A list of fish producers of all the 10 selected villages was prepared and classified into three categories based on the area under fish pond, viz., small (up to $0.97 \mathrm{ha}$ ), medium (0.98 to $2.10 \mathrm{ha}$ ) and large (2.11 ha and above), using accumulation method. A sample of 50 farmers comprising of 37 small, 9 medium and 4 large fish producers were selected in proportion to population of fish producers, by random sampling method.

\section{Analytical tools}

Maintenance cost: The maintenance cost includes $\operatorname{cost} \mathrm{A}_{1}$, $\mathrm{A}_{2}, \mathrm{~B}_{1}, \mathrm{~B}_{2}, \mathrm{C}_{1}$ and $\mathrm{C}_{2}$ as advocated by the Special Expert Committee (DADF, 1980) and are detailed below:

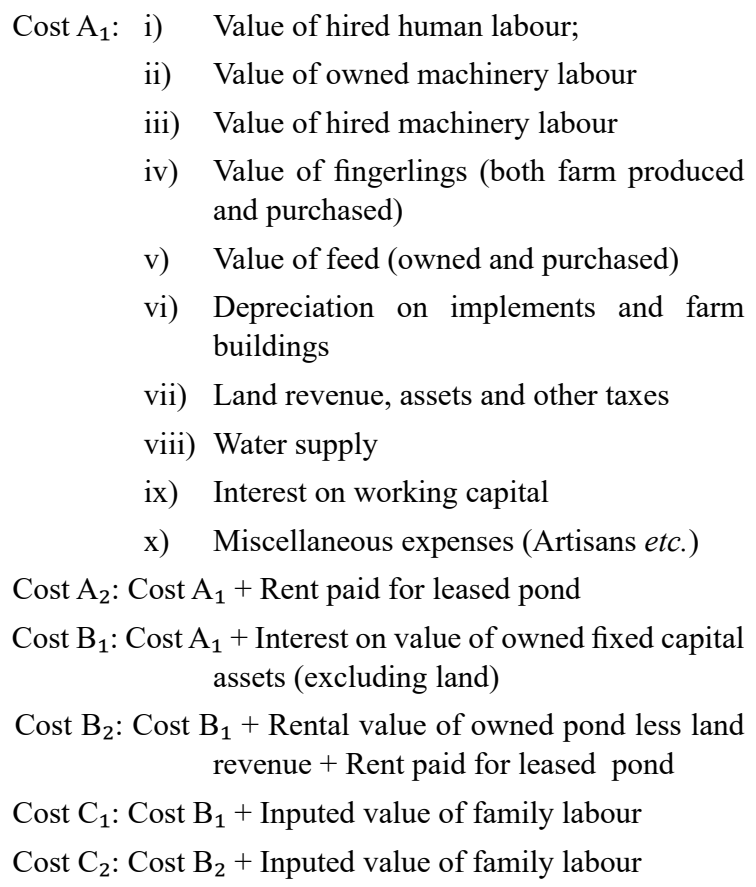

Depreciation of tools and implement: To work out the depreciation of tools and implements being used in fish production, the straight line method was used.

$$
\text { Deprectiaion }=\frac{\text { Purchase value of asset-Junk value of asset }}{\text { Useful years of asset }}
$$

Prorated establishment cost of fish pond: The standard cost components have been used to work out the economics of fish pond unit. Prorated establishment cost was computed using the formula (Sharma and Singh, 2011):

$$
\mathrm{P}_{\mathrm{c}}=\mathrm{P}(1+\mathrm{i})^{-\mathrm{n}}
$$

where, $\mathrm{P}_{\mathrm{c}}=$ Prorated establishment cost $\left(₹\right.$ pond $\left.\mathrm{d}^{-1}\right) ; \mathrm{P}=$ Initial capital investment $\left(₹\right.$ pond $\left.^{-1}\right) ; \mathrm{I}=$ Rate of interest $(8.75 \%)$ and $\mathrm{n}=$ Life span of pond (years):

Economic efficiency measure: Economic efficiency measures were worked out using the following formulae:

i. Gross farm income $(\mathrm{GFI})=$ Value of main product + Value of byproduct

ii. Net return including family labour $=$ GFI - Total cost including family labour

iii. Net return excluding family labour $=$ GFI - Total cost excluding family labour

iv. Farm business income $=$ GFI $-\operatorname{Cost} \mathrm{A}_{2}$

v. Family level income $=$ GFI - Cost $\mathrm{B}_{2}$

vi. Net farm income $=$ GFI $-\operatorname{Cost} C_{2}$

vii. Farm investment income $=$ Farm business income Wages of family labour.

Gross margin analysis: Gross margin (GM) is the difference between total revenue (TR) and total variable cost (TVC) and was determined using the formula:

$$
\mathrm{GM}=\mathrm{TR}-\mathrm{TVC}
$$

where, TVC is the difference between total cost (TC) and total fixed cost (TFC)

Net return: Net return ( $₹ \mathrm{~kg}^{-1}$ ) was computed by subtracting total cost from total revenue.

$$
\text { Net returns }=\text { Total revenue }- \text { Total cost }
$$

Benefit cost ratio (B-C Ratio): The $\mathrm{B}-\mathrm{C}$ ratio of gross income over comprehensive cost $\left(\operatorname{Cost} \mathrm{C}_{2}\right)$ was estimated using the formula:

$$
\mathrm{B}-\mathrm{C}=\frac{\mathrm{GFI}}{\operatorname{CostC2}}
$$

where GFI $=$ Gross farm income

Regression model: To identify the determinants of fish yield, Cobb-Douglas production function model was used and the estimated form of the equation was: $\begin{aligned} \text { Ln } Y= & \operatorname{In~} b_{0}+b_{1} \operatorname{In} X_{1}+b_{2} \operatorname{In} X_{2}+b_{3} \operatorname{In} X_{3}+b_{4} \operatorname{In} X_{4}+b_{5} \operatorname{In} X_{5}+b_{6} \\ & \operatorname{InX} X_{6}+b_{7} \operatorname{In} X_{7}+b_{8} \operatorname{In} X_{8}+\ln u\end{aligned}$

where, $\mathrm{Y}=$ Gross return ( $\left.₹ \mathrm{ha}^{-1}\right) ; \mathrm{X}_{1}=$ Fish pond area (ha); $\mathrm{X}_{2}=$ Prorated establishment cost $\left(₹ \mathrm{ha}^{-1}\right) ; \mathrm{X}_{3}=$ Cost of cow dung (₹ ha-1); $\mathrm{X}_{4}=$ Cost of rice bran $\left(₹ \mathrm{ha}^{-1}\right) ; \mathrm{X}_{5}=$ Cost of organic fertiliser $\left(₹ \mathrm{ha}^{-1}\right) ; \mathrm{X}_{6}=$ Cost of lime $\left(₹ \mathrm{ha}^{-1}\right) ; \mathrm{X}_{7}=$ Cost of fingerlings ( $₹ \mathrm{ha}^{-1}$ ) and $\mathrm{X}_{8}=$ Cost of labour ( $\left(\mathrm{ha}^{-1}\right)$.

\section{Results and discussion}

\section{Cost of fish production}

The cost of fish production in different size categories of fish ponds is presented in Table 1. The total cost including family labour in production of fish was 
estimated to be ₹243.56 thousand per ha which comprised of variable costs (₹76.60 thousand) and fixed costs (₹166.96 thousand). The variable cost $(32.15 \%)$ was found to be higher than the fixed cost $(67.85 \%)$ in production of fish. Similar observation was made by Asa et al. (2014) in respect to overall total average cost of fish production, in which fixed cost contributed larger share compared to variable cost. The major contribution in overall variable cost was of fingerlings $(11.88 \%)$ followed by hired labour $(6.64 \%)$, marketing cost $(5.88 \%)$, cotton or mustard seed cake and rice bran $(2.38 \%)$, bone meal (1.57\%), cow dung $(1.19 \%)$, organic fertiliser $(1.01 \%)$, interest on working capital $(1.01 \%)$ and inputed value of family labour $(0.58 \%)$. The major contribution in overall fixed cost was prorated establishment cost $(52.66 \%)$ followed by rental value of land $(14.74 \%)$, depreciation $(0.44 \%)$ and land revenue $(0.01 \%)$. Prorated establishment cost was found to be the most important item in fixed expenditure as it accounted to $52.66 \%$ of the total expenditure in fish production.

The category-wise analysis further showed that cost of fingerlings was highest in medium category and contributed $16.03 \%$ of the total production cost followed by small $(11.00 \%)$ and large $(10.73 \%)$ category respectively and the percent share on hired labour was found to be second important item in the variable expenditure. However, the percent share of variable cost in total cost was highest in medium $(40.42 \%)$ followed by small $(30.75 \%)$ and large $(26.52 \%)$ category respectively. The variable cost was highest in medium $(40.42 \%)$ category which may be due to more cost incurred on marketing cost and fingerlings inputs used by fish producers. The total fixed cost was estimated to be highest in case of small category (₹186.31 thousand); followed by large (₹171.25 thousand) and medium category (₹85.49 thousand) which may be due to higher share of prorated establishment cost of pond in small category.

Various cost concepts viz., cost A1, cost A2, cost $\mathrm{B} 1$, cost $\mathrm{B} 2$, cost $\mathrm{C} 1$ and cost $\mathrm{C} 2$ of fish production are presented in Table 2 . The category-wise analysis showed that the per ha costs i.e., cost $\mathrm{A} 1$, cost $\mathrm{A} 2$, cost $\mathrm{B} 1$, cost $\mathrm{B} 2$, cost $\mathrm{C} 1$ and cost $\mathrm{C} 2$ were estimated as highest in case of small farms; compared to medium and large category. Whereas, cost B2 and $\operatorname{cost} \mathrm{C}_{2}$ were higher in medium category compared to large category while $\operatorname{cost} \mathrm{A}_{1}, \operatorname{cost} \mathrm{A}_{2}$ $\operatorname{cost} \mathrm{B}_{1}$ and $\operatorname{cost} \mathrm{C}_{1}$ were higher in large category compared to medium category of fish producers. The total cost of cultivation ( $\operatorname{cost} \mathrm{C}_{2}$, which is known as comprehensive

Table 1. Cost of cultivation ( $₹$ in thousand $\mathrm{ha}^{-1}$ ) of fish in Gomati District of Tripura

\begin{tabular}{|c|c|c|c|c|}
\hline Particulars & Small & Medium & Large & Overall \\
\hline \multicolumn{5}{|l|}{ A. Variable cost } \\
\hline 1) Cost of fingerlings & $29.59(11.00)$ & $23.00(16.03)$ & $25.00(10.73)$ & $28.03(11.88)$ \\
\hline 2) Organic fertiliser & $3.17(1.18)$ & $1.03(0.73)$ & $0.35(0.15)$ & $2.56(1.01)$ \\
\hline 3) Cow dung & $2.90(1.08)$ & $2.53(1.76)$ & $2.19(0.93)$ & $2.78(1.19)$ \\
\hline 4) Bone meal & $3.99(1.48)$ & $3.10(2.16)$ & $2.35(1.01)$ & $3.70(1.57)$ \\
\hline $\begin{array}{l}\text { 5) Cotton or mustard seed cake and } \\
\text { rice bran }\end{array}$ & $7.03(2.61)$ & $3.12(2.17)$ & $1.76(0.76)$ & $5.90(2.38)$ \\
\hline 6) Hired labour & $18.15(6.75)$ & $9.33(6.50)$ & $14.11(6.05)$ & $16.24(6.64)$ \\
\hline 7) Inputed value of family labour & $1.99(0.74)$ & $0.26(0.18)$ & $0.16(0.06)$ & $1.53(0.59)$ \\
\hline 8) Marketing cost & $13.24(4.92)$ & $13.96(9.73)$ & $14.07(6.04)$ & $13.44(5.88)$ \\
\hline $\begin{array}{l}\text { 9) Interest on working capital @ } \\
4 \% \text { per annum }\end{array}$ & $2.67(0.99)$ & $1.69(1.18)$ & $1.84(0.79)$ & $2.43(1.01)$ \\
\hline Sub-total of A (1 to 9) & $82.72(30.75)$ & $58.01(40.42)$ & $61.82(26.52)$ & $76.60(32.15)$ \\
\hline B. Fixed cost & & & & \\
\hline 1) Rental value of land & $32.16(11.95)$ & $36.88(25.69)$ & $36.80(15.79)$ & $33.38(14.74)$ \\
\hline 2) Land revenue & $0.01(0.01)$ & $0.01(0.01)$ & $0.01(0.01)$ & $0.01(0.01)$ \\
\hline 3) Depreciation & $1.24(0.46)$ & $0.60(0.42)$ & $0.79(0.34)$ & $1.09(0.44)$ \\
\hline 4) Prorated establishment cost & $152.89(56.83)$ & $47.99(33.44)$ & $110.36(57.34)$ & $133.64(52.66)$ \\
\hline Sub-total of B (1 to 4$)$ & $186.31(69.25)$ & $85.49(59.57)$ & $171.25(73.48)$ & $166.96(67.85)$ \\
\hline $\begin{array}{l}\text { C. Total cost including } \\
\text { family labour }(\mathrm{A}+\mathrm{B})\end{array}$ & $269.03(100)$ & $143.50(100)$ & $233.08(100)$ & $243.56(100)$ \\
\hline $\begin{array}{l}\text { D. Total cost excluding family } \\
\text { labour }[(\mathrm{A}+\mathrm{B})-\mathrm{C}]\end{array}$ & 267.04 & 143.24 & 232.92 & 242.03 \\
\hline
\end{tabular}

Figures in parentheses are percentage to the total 
cost) per ha was estimated as ₹225.30 thousand, ₹211.44 thousand and ₹191.55 thousand for small, medium and large category of fish producers respectively.

\section{Return from cultured fish production}

Gross returns, farm business income, family labour income, net income and farm investment income per ha of fish was estimated considering the prevailing market price (at producer's level) of ₹ 185.50 per $\mathrm{kg}$ of fish (Table 3). Among the various categories of farms, the gross farm income was highest in case of large fish ponds (₹407.36 thousand); followed by medium (₹404.12 thousand) and small category (₹383.25 thousand). Similar trend was also found by Agboola (2011) in respect to gross farm income which was estimated higher for large fish ponds compared to other category of fish ponds. On the other hand, the farm business income was highest in medium category owing to the less deductions in terms of cost $\mathrm{A}_{2}$ in medium farms. Overall family labour income was estimated as ₹170.36 thousand. However, the net farm income of fish production was estimated to be ₹168.83 thousand per ha, in which the large farms (₹215.82 thousand) get the highest net farm income compared to medium ( $₹ 192.68$ thousand) and small farms (₹157.95 thousand). The output-input ratio for large category worked out to 2.13 as against 1.91 and 1.70 for medium and small category respectively, when this ratio was calculated over cost $\mathrm{C} 2$ (comprehensive cost). The favourable benefit cost ratios show economic viability of fish production. Similar findings were reported by Williams et al. (2012) and Emokaro et al. (2010) in catfish production.
Further, Table 4 clearly shows that the coefficient of elasticity of production (regression coefficient in terms of fish pond area (0.19) and fingerling cost (1.51) are positively significant at $1 \%$ level of significance. In terms of magnitude, $1 \%$ increase in area of pond would increase gross revenue by $0.19 \%$ and $1 \%$ increase in expenditure on fingerlings would increase the value of production by $1.51 \%$. Whereas, the regression coefficients for cow dung $(-0.01)$ turned out to be negatively significant at $5 \%$ level of significance, indicating that there was an over use of cow dung and implied that with one rupee increase in expenditure on cow dung there would be a decrease in the gross revenue by $0.01 \%$.

The value of $\mathrm{R}^{2}$ was found to be 0.52 indicating $52 \%$ variation in yield as explained by the variables included in the model. The remaining $48 \%$ of variation might be due to some other factors which have not been captured in the function such as climate and temperature.

The ratios of MVP and MFC explains economic performance of inputs. The results of the analysis presented in Table 4, revealed that MVP-MFC ratios of the inputs viz., fish pond area, prorated establishment cost, cost of rice bran, lime and labour show less scope to raise the return by using the inputs. The MVP-MFC ratio for fingerlings highlights possibilities for increasing the profitability by purchasing fingerlings for fish production. The negative ratio of cow dung and organic fertilisers indicates there was excessive use of these two inputs in the production of fish.

It can be concluded from the above analysis that fish culture is an economically feasible and profitable enterprise. The net return after subtracting the total cost

Table 2. Cost of fish production ( $₹$ in thousand ha $^{-1}$ ) using cost concepts in Gomati District of Tripura

\begin{tabular}{lllll}
\hline Cost types & Small & Medium & Large & Overall \\
\hline Cost $A_{1}$ & $81.99(36.39)$ & $58.38(27.61)$ & $62.48(32.62)$ & $76.18(34.51)$ \\
Cost $A_{2}$ & $112.87(50.10)$ & $89.89(42.51)$ & $96.43(50.34)$ & $107.42(48.75$ \\
Cost $B_{1}$ & $86.76(38.51)$ & $63.25(29.91)$ & $67.36(35.17)$ & $80.98(36.69)$ \\
Cost $B_{2}$ & $223.31(99.12)$ & $211.18(99.88)$ & $191.39(99.92)$ & $218.58(99.32)$ \\
$\operatorname{Cost} C_{1}$ & $88.75(39.39)$ & $63.50(30.03)$ & $67.52(35.25)$ & $82.51(37.38)$ \\
$\operatorname{Cost} C_{2}$ & $225.30(100)$ & $211.44(100)$ & $191.55(100)$ & $220.11(100)$ \\
\hline
\end{tabular}

Figures in parentheses are percentage to the total

Table 3. Returns of fish cultivation (₹ in thousand $\mathrm{ha}^{-1}$ ) in Gomati District of Tripura

\begin{tabular}{|c|c|c|c|c|}
\hline Particulars & Small & Medium & Large & Overall \\
\hline Gross farm income (GFI) & 383.25 & 404.12 & 407.36 & 388.94 \\
\hline Farm business income & 270.38 & 314.23 & 310.94 & 281.52 \\
\hline Family labour income & 159.94 & 192.94 & 215.98 & 170.36 \\
\hline Net farm income & 157.95 & 192.68 & 215.82 & 168.83 \\
\hline Farm investment income & 268.39 & 313.97 & 310.78 & 279.99 \\
\hline Benefit cost ratio (GFI/Cost $\left.C_{2}\right)$ & 1.70 & 1.91 & 2.13 & 1.77 \\
\hline
\end{tabular}


Table 4. Estimated Cobb-Douglas production function coefficients and MVP to MFC ratios

\begin{tabular}{llll}
\hline Particulars & Parameters & Production elasticities & MVP: MFC \\
\hline Intercept & $\mathrm{a}$ & $-3.55(3.24)$ & 0.24 \\
Fish pond area & $\mathrm{b}_{1}$ & $0.19^{* * *}(0.05)$ & 0.01 \\
Prorated establishment cost & $\mathrm{b}_{2}$ & $0.01(0.008)$ & -0.01 \\
Cow dung & $\mathrm{b}_{3}$ & $-0.01^{* *}(0.005)$ & 0.01 \\
Rice bran & $\mathrm{b}_{4}$ & $0.01(0.006)$ & -0.01 \\
Organic fertilisers & $\mathrm{b}_{5}$ & $-0.01(0.003)$ & 0.01 \\
Lime & $\mathrm{b}_{6}$ & $0.01(0.004)$ & 1.58 \\
Fingerlings & $\mathrm{b}_{7}$ & $1.51^{* * *}(0.33)$ & 0.06 \\
Labour & $\mathrm{b}_{8}$ & $0.05(0.09)$ & 0.52 \\
Coefficient of determination & $\mathrm{R}^{2}$ & 0.06 & \\
\hline
\end{tabular}

Figures in parentheses are standard errors; ${ }^{* * *}$ :Indicate significance at $1 \%$ probability level; ${ }^{* *}$ Iindicates significant at $5 \%$ probability level

including family labour was found to be more for medium farms followed by large and small category farms. The benefit cost ratio of gross farm income and cost $\mathrm{C}_{2}$ was found highest in large followed by medium and small category. Therefore, study recommends extending more research and development in this sector to enhance the area and production for ensuring sustainable livelihood and income to the farmers of the state.

\section{Acknowledgements}

Authors are thankful to the Central Agricultural University, Imphal for providing all the facilities to carry out the research work. Authors are also grateful to the anonymous reviewer for constructive comments which helped to improve the manuscript.

\section{Reference}

Agboola, W. L. 2011. Improving fish farming productivity towards achieving food security in Osun State, Nigeria: A socioeconomic analysis. Ann. Biol. Res., 2(3): 62-74.

Asa, U. A. and Obinaju, L. C. 2014. Economics of catfish production in Akwalbom State, Nigeria, Global Journal of Management and Business Research, 14(3): 23-27.
Emokaro, C. O., Ekunwe, P. A. and Achille, A. 2010. Profitability and viability of catfish farming in Kogi State, Nigeria. Res. J. Agri. Biol. Sci., 6(3): 215-219.

DADF 2013. Annual report 2013, Department of Animal Husbandry, Dairying and Fisheries, Ministry of Agriculture, Govt. of India, New Delhi.

DADF 1980. Report of the special export committee on cost of production estimates. Department of Agriculture and Cooperation, Ministry of Agriculture, New Delhi, India.

GoT 2013. Economic Review of Tripura, 2012-13. Directorate of Economics and Statistics, Government of Tripura, Agartala.

NFDB 2014. http://nfdb.ap.nic.in/html/aboutus.htm (Accessed 9 April 2014).

Sharma, M. and Singh, R. 2011. Production and marketing of fish culture in ponds in Himachal Pradesh. Indian J. Agri. Marketing, 25(2): 135-143.

Williams, S. B., Kareem, R. O. and Ojolowo, O. A. 2012. Economic analysis of catfish production in Ile-Ife, Osun State, Nigeria, J. Hum. Ecol., 40(1): 1-7. 